\title{
Isolation by distance and low connectivity in the peppery furrow shell Scrobicularia plana (Bivalvia)
}

\author{
Sílvia Santos ${ }^{1, *}$, Catarina Cruzeiroo, ${ }^{1,2}$, Jeanine L. Olsen ${ }^{3}$, Henk W. van der Veer ${ }^{1}$, \\ Pieternella C. Luttikhuizen ${ }^{1}$
}

\author{
${ }^{1}$ Royal Netherlands Institute for Sea Research (NIOZ), 1790 AB Den Burg Texel, The Netherlands \\ ${ }^{2}$ CIMAR/CIIMAR - Centro Interdisciplinar de Investigação Marinha e Ambiental, Universidade do Porto, 4050-123 Porto, \\ Portugal \\ ${ }^{3}$ Department of Marine Benthic Ecology and Evolution, Centre for Ecological and Evolutionary Studies, \\ University of Groningen, 9747 AG Groningen, The Netherlands
}

\begin{abstract}
Scrobicularia plana da Costa, 1778, a commercially important bivalve species in southern Europe, is commonly found along the NE Atlantic and Mediterranean coasts. Like other intertidal mollusk species, it has a wide distributional range and high potential for larval dispersal. However, S. plana has a patchier distribution than most co-distributed soft sediment bivalves of the intertidal, which could lead to lower interpopulation connectivity and stronger population structure. We surveyed 18 locations from throughout the species' range to determine overall population structure, phylogeographic distribution and historical demography. We sequenced a portion of the mitochondrial cytochrome-c-oxidase I gene (COI) for 423 individuals. Three population clusters (Trondheim, Atlantic and Pisa) were identified on the basis of pairwise $F_{\mathrm{ST}} \mathrm{s}$. Demographic parameters were analysed in a coalescence framework. Strong differentiation was found between most Atlantic locations and the single Mediterranean location (Pisa). Among Atlantic locations, differentiation was weak and non-significant, though significant isolation-by-distance was detected. A star-shaped phylogeny with mostly 1-step mutations was found. Although 65 haplotypes were detected, 50 were private. The higher diversity observed in southern Europe, Brittany and Norway was consistent with glacial refugia. Population expansion occurred recently with the oldest split, which was between all Atlantic groups and the Mediterranean group, taking place 0.3 to 1.1 million years ago (Myr). Negative values for neutrality tests and the star-shaped haplotype network were also indicative of recent population expansion, although such a pattern can also be the result of a selective sweep. An isolation-by-distance effect and absence of migration reveal low interpopulation connectivity, which is likely reinforced by the species' patchy spatial distribution.
\end{abstract}

KEY WORDS: Scrobicularia plana $\cdot$ Mitochondrial DNA · Genetic structure · Phylogeography · Glacial refugia Resale or republication not permitted without written consent of the publisher

\section{INTRODUCTION}

During the Pleistocene, repeated episodes of glacial advance and retreat occurred, resulting in major transformations in the geography and climate of northern Europe (Kukla et al. 2002). At the last gla- cial maximum (LGM) some $18000 \mathrm{yr}$ before present (BP), the European ice sheet extended south to $52^{\circ} \mathrm{N}$, while the permafrost extended to $47^{\circ} \mathrm{N}$ (Bradwell et al. 2008). Intrusion of ice sheets and unfavorable climate conditions beyond species' tolerance ranges pushed species south (Wares \& Cunningham 2001, 
Ilves et al. 2010). As the LGM ended, ca. $10000 \mathrm{yr}$ BP (Dawson 1992), temperatures increased, causing a northward expansion of many species from southern refugia (Hewitt 2000, Maggs et al. 2008). These shifts in latitudinal range affected population dynamics, with the present genetic structure of the species reflecting those past conditions (Hewitt 2004).

Recolonization pathways and the location of refugia can be inferred from population genetic and phylogeographic analyses of contemporary populations (Avise 2000). Numerous studies targeting species in the Atlantic Ocean and Mediterranean Sea have been conducted for benthic intertidal organisms over the past $15 \mathrm{yr}$, including a number of bivalves and gastropods such as baltic tellin Macoma balthica (Luttikhuizen et al. 2003), northern quahog Mercenaria mercenaria (Baker et al. 2008), blue mussel Mytilus edulis (Riginos \& Henzler 2008), blue mussel M. trossulus (Rawson \& Harper 2009), softshell clam Mya arenaria (Strasser \& Barber 2009), lagoon cockle Cerastoderma glaucum (Tarnowska et al. 2010), and common cockle C. edule (Krakau et al. 2012). In virtually all studies, the Atlantic and Mediterranean are well separated and a number of refugia have been identified in Northern Spain, Brittany, SW Ireland and the Lofoten area of Scandinavia (Fucus distichus, Coyer et al. 2011). Genetic diversity patterns typically follow the 'southern richness, northern purity' (Hewitt 2000) model of allelic/haplotypic richness or modifications involving population admixtures (reviewed in Maggs et al. 2008). High allelic/ haplotypic richness in northern latitudes has, so far, only been observed in the cockle $C$. edule (Krakau et al. 2012) and the fucoid seaweed F. distichus (Coyer et al. 2011).

In addition to historical factors, contemporary population dynamics also shape population genetic and phylogeographic structure. This is especially true in species whose life-history traits include planktonic larval stages of considerable duration, in which case demographic contact is expected to lead to 'open' populations, successful gene flow and, ultimately, greater inter-population connectivity (Swearer et al. 2002, Selkoe \& Toonen 2011). Examples of this are often found in fish (Riginos \& Victor 2001, Hoarau et al. 2002, Bradbury \& Bentzen 2007, Reece et al. 2011) mollusks (Becker et al. 2007, Crandall et al. 2010, Hoffman et al. 2011) and crustaceans (Palero et al. 2008, Domingues et al. 2010). More complex patterns can also be caused by regional to local oceanographic currents and their interactions with the topography and habitat (e.g. Barber et al. 2000, Shanks et al. 2003, Cowen et al. 2007, Galarza et al. 2009, White et al. 2010). In some cases retention zones may be formed (e.g. Bradbury et al. 2008, Cowen \& Sponaugle 2009, Galindo et al. 2010, Small \& Wares 2010), which suggests that the link between pelagic larval duration and connectivity in marine systems is not that straightforward (e.g. Lester et al. 2007, Weersing \& Toonen 2009, Riginos et al. 2011). Analysis of the geographic pattern of genetic variation should allow, however, a better understanding of the relationship between the population structure of a species and its ecological and habitat characteristics.

The interest in molecular studies of bivalve species stems from the central role that these organisms play in intertidal soft-sediment ecosystems (e.g. Thrush et al. 2006). Assessment of genetic variation and population differentiation throughout their geographical range is crucial for the preservation of natural populations. In intertidal soft-sediment areas of NW Europe, Macoma balthica, Cerastoderma edule, Abra tenuis and Scrobicularia plana are the 4 most common and abundant bivalve species (Bocher et al. 2007). High population subdivision has been observed for $M$. balthica in spite of the species' potential for high gene flow (e.g. Luttikhuizen et al. 2003, Väinölä 2003). Geographically structured populations were also found for $C$. edule, with a significant isolation-by-distance in northern populations (Krakau et al. 2012). A similar structure was observed for A. tenuis, which was, however, expected for this species since $A$. tenuis has a direct development, i.e. no planktonic larval stage (Holmes et al. 2004). As for $S$. plana, although a survey of population structure using allozymes found high within-population variation (Skibinski et al. 1978), the authors did not address interpopulation connectivity. While all 4 species have a wide distributional range, $A$. tenuis and $S$. plana are characterized by a patchier spatial distribution (Bocher et al. 2007), which is expected to affect population connectivity and in $S$. plana's case is not predicted from its life history, namely dispersal mode (Johnson et al. 2001).

Scrobicularia plana is a temperate species that occurs along the NE Atlantic coast, from the Norwegian Sea to Senegal, as well as in the Mediterranean Sea (Tebble 1976). The species inhabits intertidal areas with soft bottoms (sand, clay or mud), rich in organic matter, but has a clear preference for muddy sediments (Bocher et al. 2007). S. plana is an important component of shallow-water benthic communities and is of commercial importance in southern Europe (Tebble 1976, Keegan 1986). The species is gonochoristic, with planktotrophic development and an average pelagic life stage of 2 to $4 \mathrm{wk}$ (Frenkiel \& 
Mou za 1979). After hatching (and before the settling pediveliger stage), veligers dwell in a totally pelagic environment, a stage during which larvae are capable of dispersal (Frenkiel \& Mouëza 1979).

The aim of the present study is to identify LGM refugia and to infer the historical demography of Scrobicularia plana using mitochondrial DNA data analyzed in a coalescence framework. Moreover, the genetic structure and connectivity of $S$. plana populations will be analyzed along the species' distributional range.

\section{MATERIALS AND METHODS}

\section{Sampling}

Scrobicularia plana adults were collected at 18 locations along the species' distributional range (from Baltic and North Sea to the Northeast Atlantic Ocean and Mediterranean Sea), during the period of 2007 to 2009 (Table 1). Animals were collected in intertidal areas during low tide and were immediately preserved in $95 \%$ ethanol. Next, a tissue sample was removed from each animal and stored at $-20^{\circ} \mathrm{C}$ until DNA extraction.

\section{Molecular protocols}

DNA was extracted using the GenElute ${ }^{\mathrm{TM}}$ Mammalian Genomic DNA kit (SIGMA ${ }^{\circledR}$ ) according to the Mammalian Tissue protocol (Part B), provided by the manufacturer. Extracted DNA was visualized on $1 \%$ Tris-Borate-EDTA (TBE) agarose gels to assess quantity and quality.

Universal primers HCO2198 and LCO1490 (Folmer et al. 1994) were used to amplify a $710 \mathrm{bp}$ fragment of the mitochondrial cytochrome-c-oxidase subunit I region (COI) gene. PCR amplifications were carried out in a $50 \mu \mathrm{l}$ reaction containing $5 \mu \mathrm{l}$ template DNA (1:10 dilution of DNA), $4.6 \mu \mathrm{l} 10 \times$ reaction buffer (Biotherm ${ }^{\mathrm{TM}}$ ), $4.6 \mu \mathrm{l}$ deoxynucleoside triphosphate $(\mathrm{dNTP} ; 2.5 \mu \mathrm{mol}), 0.3 \mu \mathrm{l}$ of each primer $(0.02 \mu \mathrm{mol})$ and $0.25 \mu \mathrm{l} \mathrm{Taq}$ polymerase (Biotherm Plus ${ }^{\mathrm{TM}}$ ). The amplification reaction was performed with an initial denaturation step of $5 \mathrm{~min}$ at $94^{\circ} \mathrm{C}$, followed by 35 cycles of $94^{\circ} \mathrm{C}$ denaturation for $30 \mathrm{~s}, 40^{\circ} \mathrm{C}$ annealing for $45 \mathrm{~s}, 45 \mathrm{~s}$ extension at $72^{\circ} \mathrm{C}$, and a final $7 \mathrm{~min}$ extension at $72^{\circ} \mathrm{C}$ during the last cycle.

Twenty-three sequences were aligned and speciesspecific primers, CO_SCROB_F (5'-TTG GGA GTC TTT ATT TTG TTT TAG-3') and CO_SCROB_R (5'AAG AAA GAA GTA TTA AAA TTA CGA TCA-3'), were designed using Primer3 (Rozen \& Skaletsky 2000). The specific primers, used for the remaining sequences, amplified a $622 \mathrm{bp}$ fragment. The PCR reaction was identical except for an annealing temperature of $50^{\circ} \mathrm{C}$.

Amplifications were confirmed by $2 \%$ TBE agarose gel electrophoresis. In some cases, re-amplification was necessary and performed as follows: a small portion of the DNA band of the gel was collected and transferred into a $1.5 \mathrm{ml}$ tube; $200 \mu \mathrm{l}$ of sterile water was then added and the tube incubated for $2 \mathrm{~min}$ at $95^{\circ} \mathrm{C}$; and $1 \mu \mathrm{l}$ of solution was used as template for

Table 1. Scrobicularia plana. Sample locations and sample sizes

\begin{tabular}{|c|c|c|c|c|c|}
\hline Location & Latitude & Longitude & Sampling date & Code & $\mathrm{n}$ \\
\hline Trondheim, Norway & $63^{\circ} 18^{\prime} 60.88^{\prime \prime} \mathrm{N}$ & $10^{\circ} 11^{\prime} 01.74^{\prime \prime} \mathrm{E}$ & April 2008 & TRO & 29 \\
\hline Tjärnö, Sweden & $58^{\circ} 53^{\prime} 32.94^{\prime \prime} \mathrm{N}$ & $11^{\circ} 10^{\prime} 04.14^{\prime \prime} \mathrm{E}$ & October 2007 & $\mathrm{TJ}$ & 26 \\
\hline Killala Bay, Ireland & $54^{\circ} 13^{\prime} 34.62^{\prime \prime} \mathrm{N}$ & $09^{\circ} 12^{\prime} 43.14^{\prime \prime} \mathrm{W}$ & March 2008 & KB & 23 \\
\hline Wadden Sea, Germany & $53^{\circ} 42^{\prime} 49^{\prime \prime} \mathrm{N}$ & $07^{\circ} 48^{\prime} 04^{\prime \prime} \mathrm{E}$ & May 2007 & WS & 32 \\
\hline Balgzand, Netherlands & $52^{\circ} 56^{\prime} 09^{\prime \prime} \mathrm{N}$ & $04^{\circ} 48^{\prime} 07.20^{\prime \prime} \mathrm{E}$ & March 2008 & BA & 27 \\
\hline King's Lynn, England & $52^{\circ} 49^{\prime} 14.30^{\prime \prime} \mathrm{N}$ & $00^{\circ} 17^{\prime} 16.60^{\prime \prime} \mathrm{E}$ & February 2008 & $\mathrm{KL}$ & 30 \\
\hline Clonakilty Estuary, Ireland & $51^{\circ} 37^{\prime} 17.50^{\prime \prime} \mathrm{N}$ & $08^{\circ} 52^{\prime} 40.39^{\prime \prime} \mathrm{W}$ & April 2008 & CLO & 29 \\
\hline Terneuzen, Netherlands & $51^{\circ} 20^{\prime} 47.76^{\prime \prime} \mathrm{N}$ & $03^{\circ} 47^{\prime} 44.52^{\prime \prime} \mathrm{E}$ & May 2008 & TER & 29 \\
\hline Plymouth, England & $50^{\circ} 12^{\prime} 35^{\prime \prime} \mathrm{N}$ & $05^{\circ} 05^{\prime} 27^{\prime \prime} \mathrm{W}$ & January 2008 & PLY & 20 \\
\hline Roscoff, France & $48^{\circ} 40^{\prime} 18.83^{\prime \prime} \mathrm{N}$ & $04^{\circ} 03^{\prime} 26.13^{\prime \prime} \mathrm{W}$ & April 2009 & $\mathrm{RO}$ & 25 \\
\hline Moeze plaisance, France & $45^{\circ} 55^{\prime} 15.29^{\prime \prime} \mathrm{N}$ & $01^{\circ} 04^{\prime} 31.11^{\prime \prime} \mathrm{W}$ & March 2008 & MP & 19 \\
\hline Astúrias, Spain & $43^{\circ} 34^{\prime} 59.79^{\prime \prime} \mathrm{N}$ & $10^{\circ} 18^{\prime} 00.43^{\prime \prime} \mathrm{E}$ & April 2007 & AS & 17 \\
\hline Pisa, Italy & $43^{\circ} 28^{\prime} 00^{\prime \prime} \mathrm{N}$ & $05^{\circ} 26^{\prime} 00^{\prime \prime} \mathrm{W}$ & July 2008 & PI & 30 \\
\hline Ponte Vedra, Galicia & $42^{\circ} 28^{\prime} 00.57^{\prime \prime} \mathrm{N}$ & $08^{\circ} 42^{\prime} 10.50^{\prime \prime} \mathrm{W}$ & April 2007 & PV & 9 \\
\hline Caminha, Portugal & $41^{\circ} 53^{\prime} 08.00^{\prime \prime} \mathrm{N}$ & $08^{\circ} 50^{\prime} 50.40^{\prime \prime} \mathrm{W}$ & February 2008 & $\mathrm{CA}$ & 26 \\
\hline Algarve, Portugal & $37^{\circ} 07^{\prime} 37.60^{\prime \prime} \mathrm{N}$ & $07^{\circ} 36^{\prime} 36.40^{\prime \prime} \mathrm{W}$ & April 2008 & $\mathrm{AL}$ & 24 \\
\hline Cádiz, Spain & $36^{\circ} 52^{\prime} 31.50^{\prime \prime} \mathrm{N}$ & $06^{\circ} 20^{\prime} 44^{\prime \prime} \mathrm{W}$ & May 2007 & $\mathrm{CZ}$ & 11 \\
\hline Agadir, Morocco & $30^{\circ} 21^{\prime} 50.03^{\prime \prime} \mathrm{N}$ & $09^{\circ} 35^{\prime} 41.80^{\prime} \mathrm{W}$ & July 2006 & $\mathrm{AG}$ & 17 \\
\hline
\end{tabular}


the PCR reaction. After confirmation, fragments were purified directly, using QuickClean 5M PCR Purification Kit (GenScript).

Sequencing was carried out by Macrogen (Seoul, South Korea), using ABI-BigDye ${ }^{\mathrm{TM}}$ terminator cycling conditions and sequenced on an ABI 3730XL Gene Analyzer.

\section{Population genetic and phylogeographical analysis}

Sequences were aligned with BioEdit version 7.0.9.0 (Hall 1999) and reduced to a 507 bp length. All polymorphisms were double-checked on the chromatograms. Haplotypes were detected with the help of sequence analysis toolbox FaBox version 1.35 (Villesen 2007). Genetic variation was estimated as haplotype diversity $h$ (Nei 1987) and as nucleotide diversity $\pi$ (Tajima 1983, Nei 1987) with Arlequin version 3.1 (Excoffier et al. 2005). A minimum spanning network among the haplotypes was determined using Arlequin version 3.1 (Excoffier et al. 2005).

Differentiation between sampling locations was estimated on the basis of pairwise $F$-statistics $\left(F_{\mathrm{ST}}\right)$ using both conventional $F_{\mathrm{ST}}$ statistics and the Kimura 2-parameter model (K2P) (Kimura 1980) in Arlequin version. 3.1. The K2P model was the model implemented in Arlequin version 3.1 that fit our data best according to the test performed in jModeltest version 0.1.1 (Guindon \& Gascuel 2003, Posada 2008). While conventional $F_{\mathrm{ST}}$ considers haplotype frequencies only, the K2P model takes genetic distances into account, allowing correction for multiple substitutions per site and different substitution rates between transitions (TI) and transversions (TV). The significance of the statistics was computed using 10000 permutations of the original data matrices to generate null distributions of pairwise $F_{\text {ST }}$ values under the hypothesis of no difference between the populations. An analysis of molecular variance (AMOVA) based on the K2P model was also conducted in Arlequin version 3.1 in order to estimate the degree of genetic structuring for mtDNA-COI sequences among and within populations or groups. To test the significance of covariance components and fixation indices, 10000 permutations were performed. To address the problem of multiple comparisons, probability levels were adjusted using the False Discovery Rate (FDR) correction procedure (Benjamini \& Hochberg 1995), which controls for the expected proportion of incorrectly rejected null hypotheses (Type I errors).

To test for evidence of isolation-by-distance, a Mantel test was performed on genetic distances
$\left[F_{\mathrm{ST}} /\left(1-F_{\mathrm{ST}}\right)\right]$ against (linear) geographic distance (minimum coastline distance) between all pairs of sampling locations, using the isolation by distance web service (IBDWS) version 3.21 (Jensen et al. 2005). In a 1-dimensional habitat (considered as such given that differentiation occurs over spatial scales greater than the habitat width) a linear relationship between these 2 variables is expected (Rousset 1997). The significance of Mantel's $Z$ test statistic was based on 30000 permutations.

Population clusters were identified using pairwise $F_{\mathrm{ST}}$ values and a minimum spanning network in which groupings were formed based on the existence of significant differences between populations and geographically identifiable clusters. This was done in order to apply a population model for estimation of demographic parameters.

To infer historical demographic expansions, pairwise mismatch distributions were generated for the different groups, with DnaSP version 5.10 (Librado \& Rozas 2009), and the raggedness $r$ index was calculated (Harpending 1994). This analysis tests a null hypothesis of population expansion with the failure to reject it (non-significant raggedness index) indicating lack of support for the alternative hypotheses of population stability. Departure from neutrality (as would be expected under population expansion) was also tested using R2 (Ramos-Onsins \& Rozas 2002), in DnaSP v. 5.10, and Fu's Fs (Fu 1997) and Tajima's D (Tajima 1989), in Arlequin version 3.1 by generating 10000 simulated samples under the hypothesis of selective neutrality and stable population size.

Estimation of divergence time was obtained under an isolation-with-migration analytical model (IMa2; Hey 2010). The program uses a Markov chain Monte Carlo (MCMC) simulation. The model assumes that an ancestral population of size $\theta_{\mathrm{A}}$ split into 2 populations of sizes $\theta_{1}$ and $\theta_{2}$, t generations ago and that the 2 populations exchanged migrants with rates $m_{1}$ and $m_{2}$ after divergence. The demographic parameters estimated by IMa2 are scaled by the following: (1) mutation rate $\mu$ : $\theta=4 \mathrm{~N}_{\mathrm{e}} \mu$ for nuclear genes, where $N_{\mathrm{e}}$ is the effective population size; (2) $t=t \mu$, where $t$ is the time since splitting in units of years; and (3) $m=m$ $/ \mu$, where $m$ is the migration rate and $m$ is the rate per gene per generation in the coalescent. To convert the estimates of IMa2 into demographic units, an inheritance scalar of 0.25 for mitochondrial data (i.e. $\theta=$ $\mathrm{N}_{\mathrm{e}} \mu$ ) and a generation time of $2 \mathrm{yr}$ were assumed. The mutation rate $\mu$ for COI was assumed to be between $0.355 \times 10^{-6}$ and $1.315 \times 10^{-6}$ substitutions per sequence per year, based on a molecular clock calibrated by Luttikhuizen et al. (2003). Divergence rates 
were calculated based on fossil record dates from 3 distinct sets: (1) the family Arcidae (Arca spp. versus Barbatia spp., Cox et al. 1969); (2) the mussel genus Mytilus (M. californianus versus $M$. edulis species complex, Coan et al. 2000); and (3) the Tellinacea (Donax spp. versus Macoma spp. and Sinonovacula constricta versus Donax spp. and Macoma spp., Pohlo 1982). For all IMa2 runs the Hasegawa-Kishino-Yano (HKY) substitution model was used.

Pairs of populations were compared because it was not possible to fit a regular 3-population model to data from 1 single locus (due to the high number of demographic parameters). All individuals were included in the analysis. Upper limits to parameter priors were determined based on preliminary runs to ensure that posterior distributions fell completely within the prior distributions. The analysis was performed using 4 independent runs with identical priors and number of coupled chains, but different random number seeds, for each pair of populations. Three shorter runs consisting of $10 \mathrm{MCMC}$ chains with geometric heating $\left(h_{1}=0.99, h_{2}=\right.$ 0.75) of 2 million steps plus 1 longer run of 10 million steps were sampled after an initial burn-in period of 1 million steps. To reduce the number of parameters in the model, a single migration parameter was estimated for each pair of populations (equal migration rate in both directions, -j2 option). To ensure convergence of parameter distributions, effective sample size (ESS) values, autocorrelation values and chain swapping were examined; trendline plots were checked for absence of trends, and parameter distributions were checked for unimodality. Genealogies from the 4 runs were then combined in a single L-mode run and the peaks of the marginal posterior distributions were taken as estimates of the parameters.

\section{RESULTS}

\section{Sequence data}

A total of 423 individuals were sequenced and 65 different haplotypes were detected among the samples (Genbank accession numbers JN176805 to JN176869). Among the haplo- types, 58 of 507 sites were polymorphic (Table S1 in the supplement at www.int-res.com/articles/suppl/ m462p111_supp.pdf), with 2 different substitutions being observed in 5 of those sites adding up to a total of 63 substitutions, of which 48 were transitions and 15 were transversions (TI/TV ratio $=3.2$ ). Of the 63 substitutions, 17 were nonsynonymous replacement substitutions while the remaining 46 were synonymous substitutions $(\mathrm{Ka} / \mathrm{Ks}$ ratio $=0.37)$.

\section{Population genetic analysis}

The frequency of haplotypes as well as nucleotide and gene diversities and their standard deviations per sample are given in Table S2 in the supplement. Haplotype h01 was clearly the most common haplotype (67.1\% of the individuals analyzed) and the only one present at all sampling sites. The minimum spanning network showed only 1 main clade based on the presence of h01 (Fig. 1). To connect all observed hap-

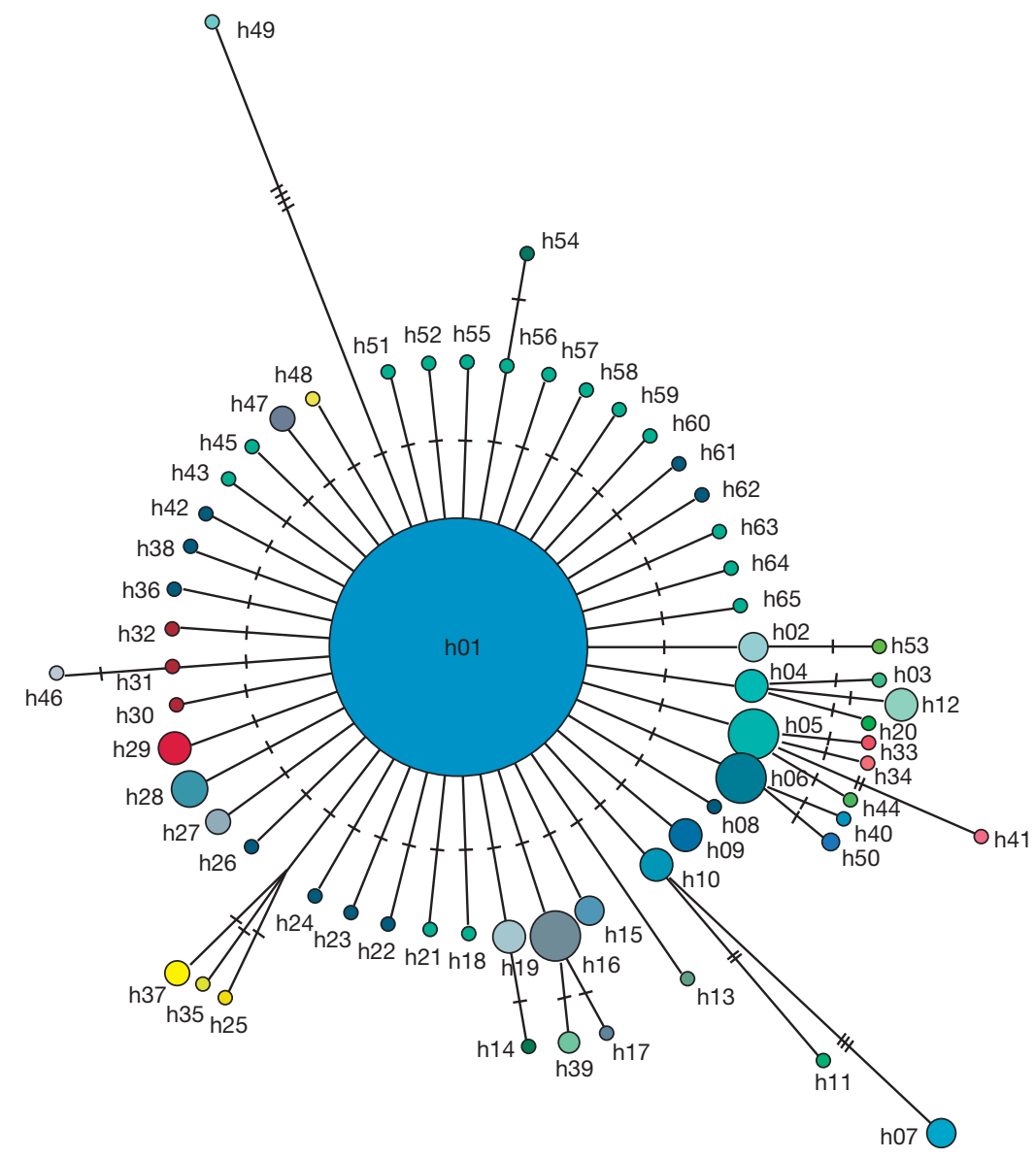

Fig. 1. Scrobicularia plana. Minimum spanning network among haplotypes, where each circle represents a haplotype; size of circles is proportional to haplotype frequency and slash marks indicate the number of substitutions. Locations in different colors: Trondheim (yellow), Atlantic (blue/green) and Pisa (red) 
lotypes to the network, the number of necessary substitutions varied between 1 and 5. The geographical distribution of all haplotypes is shown in Fig. 2. The number of observed haplotypes within populations ranged from 3 (Ponte Vedra, Galicia) to 14 (Algarve, Portugal). The majority of haplotypes (50 of 65) were private alleles, i.e. observed only in 1 population, of which 47 were single occurrences. Haplotype diversity $(h)$ ranged from 0.32 in Ireland to 0.86 in the south of Portugal with an overall average of 0.52 (Table S2 in the supplement). The lowest values of nucleotide diversity $(\pi=0.0007)$ were observed in

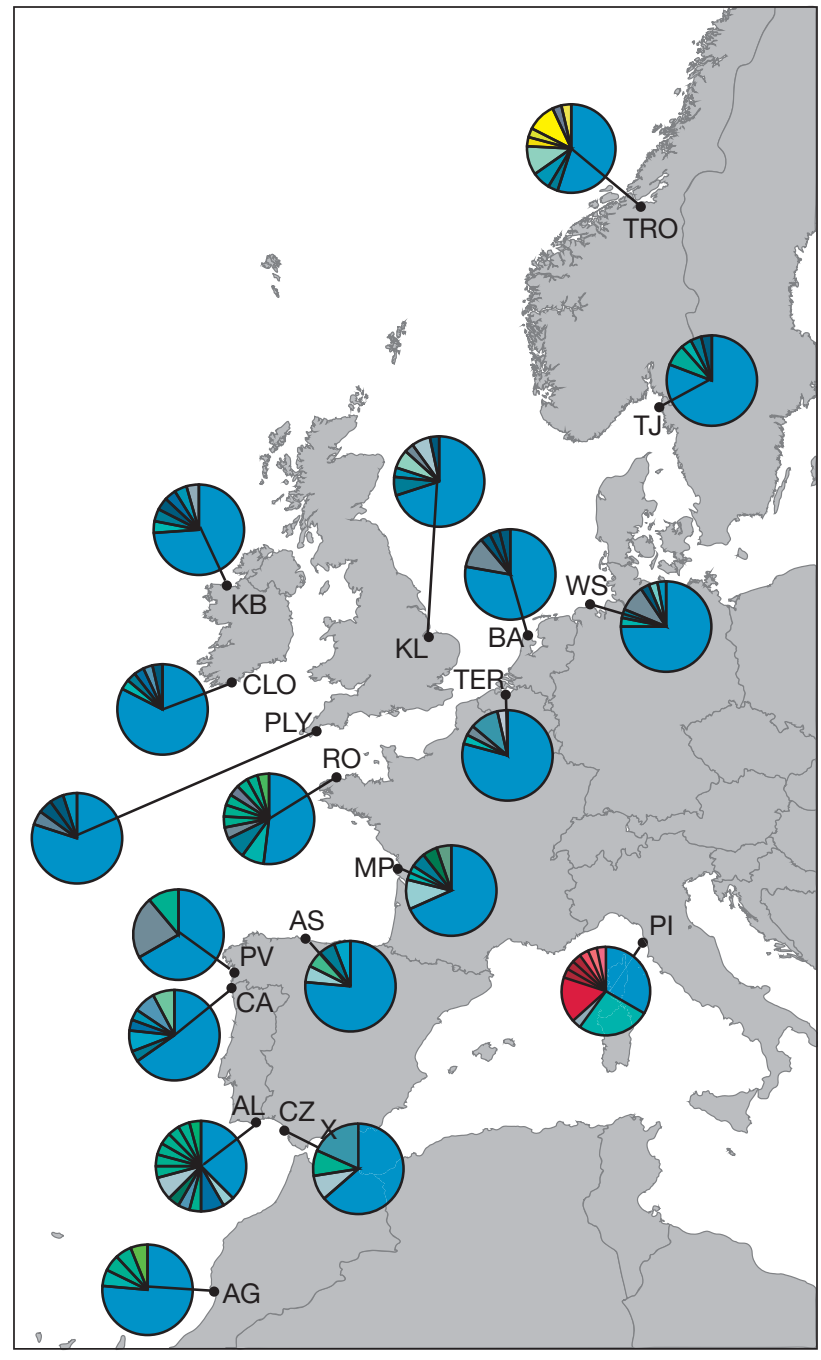

Fig. 2. Scrobicularia plana. Distribution of mitochondrial cytochrome- $c$-oxidase I haplotypes across the Northeastern Atlantic coast and Mediterranean Sea. Different colors represent haplotypes that are only found in the respective groups: Trondheim (yellow) and Pisa (red); the Atlantic group (blue/green) includes all remaining haplotypes. The different shades of each color represent a different haplotype. Letters indicate sample codes (See Table 1 for abbreviations of sample codes)
Sweden and Ireland, while the highest value (0.0029) was detected in the south of Portugal. Mean nucleotide diversity among all locations was 0.0016 indicating that, on average, individuals differed by less than $0.2 \% \mathrm{bp}^{-1}$. No significant correlation was observed between latitude and either haplotype diversity ( $p=0.25$ ) or nucleotide diversity $(p=0.33)$.

Pairwise $F_{\mathrm{ST}}$ values after FDR correction for multiple testing are shown for all samples in Tables 2 \& S3 (in the supplement). Statistically significant differences were observed in 15 of the 153 pairwise population comparisons when using the K2P model, and in 18 out of 153 when using conventional $F_{\text {ST }}$ statistics. The AMOVA showed that the global $F_{\text {ST }}$ value across all samples amounted to 0.036 , with $96.44 \%$ of the variation being explained by differences within populations, while only a small percentage (3.56\%) resulted from differences among populations. The correlation between genetic $\left[F_{\mathrm{ST}} /\left(1-F_{\mathrm{ST}}\right)\right]$ and geographic distances is presented in Fig. 3. The Mantel test showed a highly significant positive correlation between genetic divergence of populations and linear geographic distances among all samples $(Z=$ 11909.48, $\mathrm{r}=0.63$; null hypothesis of $\mathrm{r} \leq 0$ : 1 -sided $\mathrm{p}=0.0001$ from 30000 randomizations; slope with a value of $3.91 \times 10^{-5}$ and $\mathrm{R}^{2}$ of 0.40 ). A significant isolation-by-distance effect was also detected when analyzing the Atlantic cluster only $(\mathrm{p}=0.041)$.

Tests to detect additional geographic structure were performed by grouping the samples in to 3 clusters: Trondheim, Atlantic (Tjärnö, Sweden; Wadden Sea, Germany; Balgzand, Netherlands; Terneuzen, Nether-

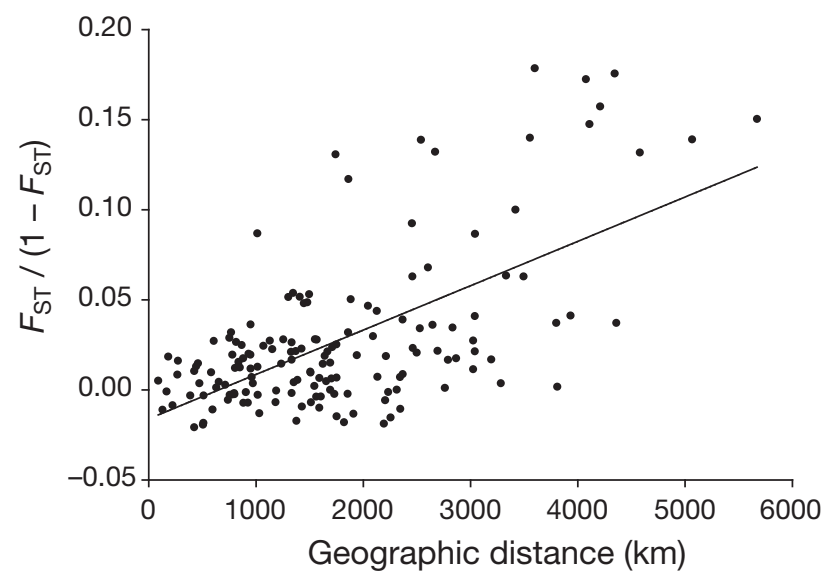

Fig. 3. Scrobicularia plana. Isolation-by-distance determined from the relationship between genetic distances $\left[F_{\mathrm{ST}} /\left(1-F_{\mathrm{ST}}\right)\right]$ were plotted against geographical distance (minimal coastline distance) between all sites. Mantel test for matrix correlation: $Z=11909.48, \mathrm{r}=0.63$; null hypothesis of $r \leq 0: 1$-sided $p=0.0001$ from 30000 randomizations. The slope had a value of $3.91 \times 10^{-5}$ and $\mathrm{R}^{2}$ of 0.40 


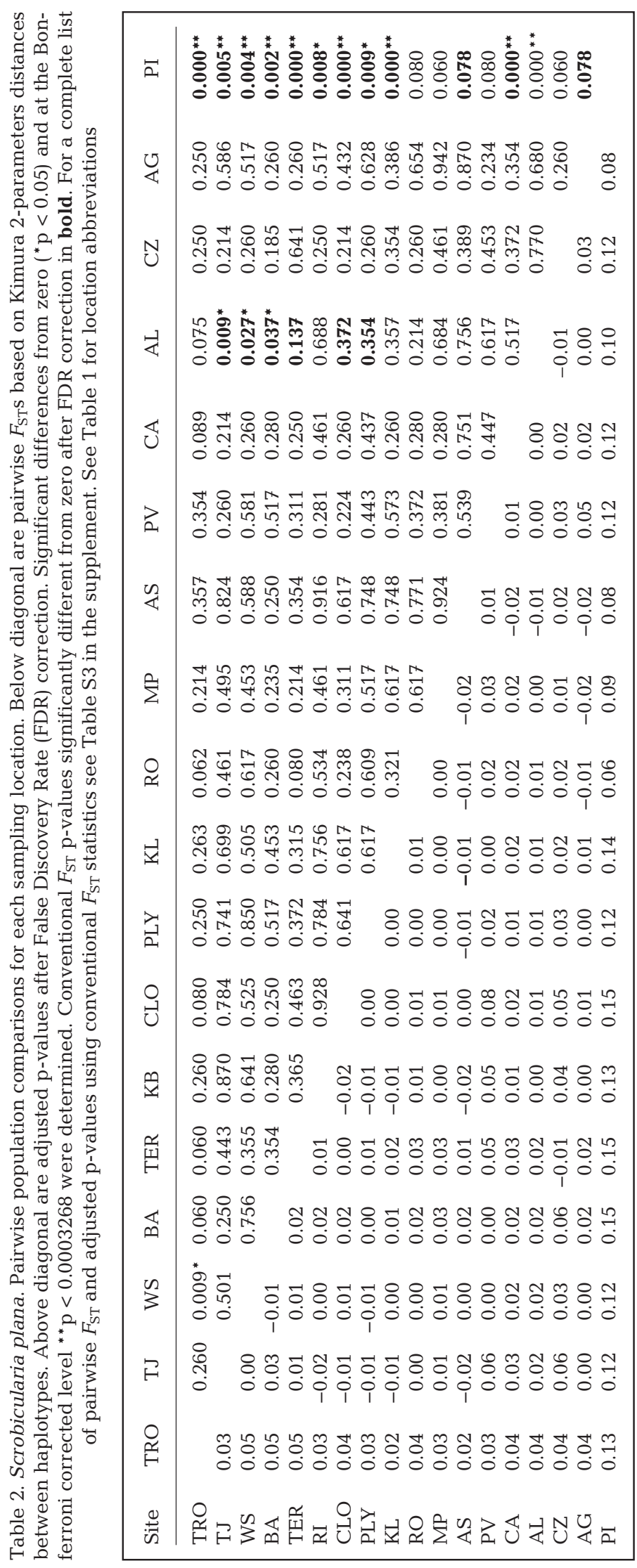

lands; Killala Bay, Ireland; Clonakilty Estuary, Ireland; Plymouth, England; Kings' Lynn, England; Roscoff, France; Moezeplaisance, France; Astúrias, Spain; Ponte Vedra, Galicia; Caminha, Portugal $_{;}$Algarve, Portugal; Cádiz, Spain; Agadir, Morocco) and Pisa. Pisa was considered a different group given the significant differences in pairwise $F_{\mathrm{ST}}$ values between Pisa and 11 other populations. As for the Trondheim cluster, its placement in a distinct group was justified by significant pairwise $F_{\mathrm{ST}}$ values (Table 2 ) and the identifiable cluster formed by 3 of its private alleles (Fig. 1), which constitutes the only geographically restricted clade observed in the haplotype network. Results from the AMOVA analysis revealed evidence of differentiation among the 3 groups $\left(F_{\mathrm{CT}}=0.111, \mathrm{p}=0.019\right)$ as well as significant variance among populations within groups $\left(F_{\mathrm{SC}}=0.003, \mathrm{p}<0.001\right)$ and among individuals within populations $\left(F_{\mathrm{ST}}=0.114\right.$, $\mathrm{p}<0.001$ ). The percentage of total molecular variation was $88.57 \%$ within groupings, $0.31 \%$ among samples within groups and $11.12 \%$ among groups, indicating that the majority of variation observed was explained by differences within populations.

\section{Historical demography}

Significant departure from neutrality, as determined by R2 and Fu's FS tests was observed for all 3 groups (Table 3). Similar results were obtained with the Tajima's D test, although the Trondheim sample was non-significant in this case, which may be due to the higher power of R2 and Fu's FS tests (Ramos-Onsins \& Rozas 2002). Mismatch distributions of the 3 groups are shown in Fig. 4. Two of the groups were characterized by a clear unimodal distribution, while Trondheim seems to also have a unimodal distribution that has apparently been under sampled. Visually, the Atlantic group fit a typical L-shaped curve, while Trondheim and Pisa were closer to a bell-shaped curve. All groups were characterized by low and non-significant raggedness values (not shown).

Population size $(\theta)$, migration $(m)$ and splitting time $\left(t_{\mathrm{s}}\right)$ parameters were estimated for Trondheim, Atlantic and Pisa groups (Table 4). Although we were unable to obtain high ESS values, the lack of a pattern in the trend line plots, high swapping rates, low autocorrelations 
Table 3. Scrobicularia plana. Tests of neutrality within the 3 groups

\begin{tabular}{|llcl|}
\hline Groups & \multicolumn{1}{c}{ Fu's FS (p-value) } & Tajima's D (p-value) & R2 (p-value) \\
\hline Trondheim & $-3.953(0.007)$ & $-1.500(0.059)$ & $0.063(0.001)$ \\
Atlantic & $-3.403 \times 10^{38}(0.000)$ & $-2.555(0.000)$ & $0.009(0.010)$ \\
Pisa & $-5.357(0.001)$ & $-1.535(0.046)$ & $0.064(0.006)$ \\
\hline
\end{tabular}

and similarity of posterior estimates generated from different runs suggested convergence in most parameters (Fig. S1 in the supplement). The splits between the Mediterranean and all other Atlantic groups appear to be the oldest at between 0.30 and 1.10 million years ago (Mya). The splitting time between Trondheim and Atlantic is estimated to have been more recent, occurring 0.10 to 0.37 Mya. Migration rates were estimated to be extremely low among all 3 groups.

\section{DISCUSSION}

\section{Population structure}

Our analysis of mitochondrial sequences of Scrobicularia plana revealed weak population structure along the species distributional range. Low levels of differentiation were indicated by low $F_{\mathrm{ST}}$ values between populations and groupings. Minimal population structure can be attributed to both a recent expansion and high gene flow. Negative values of neutrality tests point to an excess of low frequency polymorphisms indicating population expansion following a bottleneck or selective sweep (Tajima 1989). This fits well with the topology of the haplotype network, which is dominated by a single, high frequency, ancestral haplotype and many 1-step peripheral ones (Slatkin \& Hudson 1991). Demographic events can also be inferred from the mismatch analysis, as the distribution of pairwise differences is shaped by episodes of population growth or decline (Rogers \& Harpending 1992). Under population growth or directional selection, the mismatch distribution is smooth and unimodal with low raggedness values, whereas ragged multimodal distributions result from long-term stationary populations (Harpending 1994). The unimodal distributions of all the groups are indicative of recent population expansion with the Lshaped distributions of the Atlantic group suggesting a recent genetic bottleneck, with the subsequent rapid population expansion creating a 'wave' in the distribution that will shift to the right over time (Rogers \& Harpending 1992). The non-significant raggedness values observed for all groups are also indicative of expanding populations.

Species with a pelagic larval life stage, such as Scrobicularia plana, are expected to show high gene flow between populations as a consequence of their high dispersal potential in combination with the

Fig. 4. Scrobicularia plana. Mismatch distribution of mitochondrial cytochrome- $c$-oxidase I sequences for 3 locations showing (gray bars) observed distribution of pairwise differences among individuals from each group and (black line) expected distribution under a model of sudden expansion 


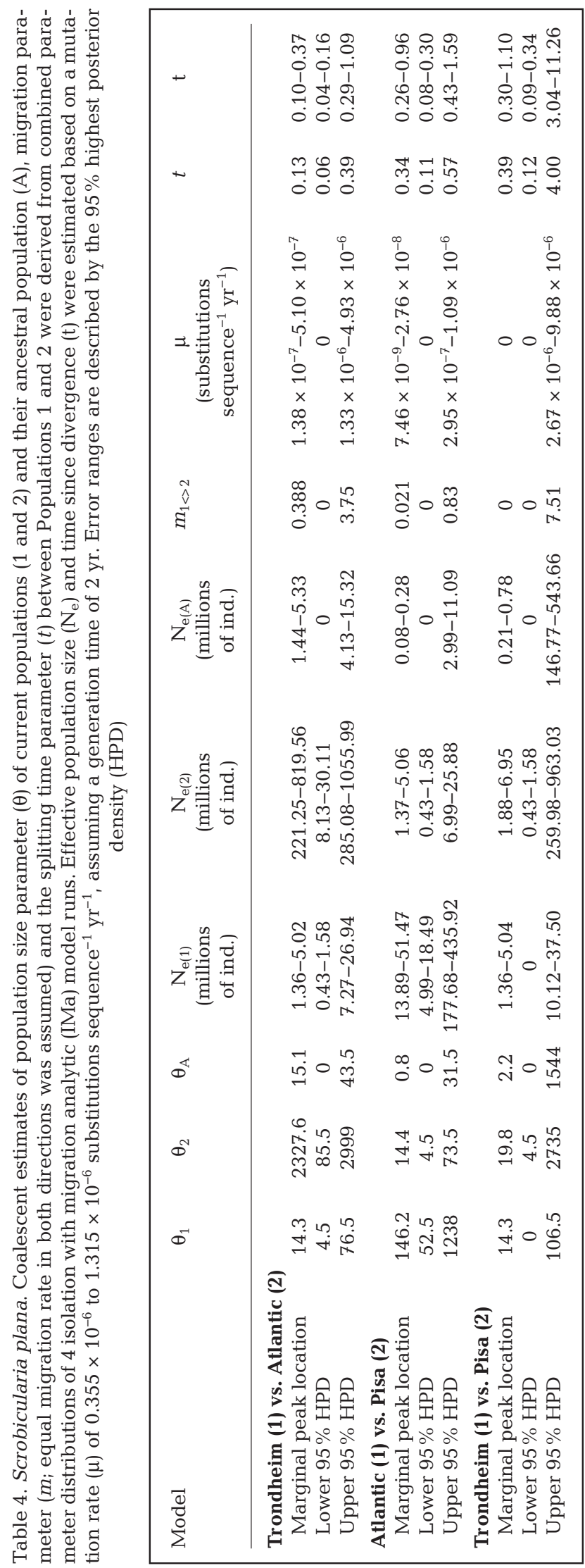

apparent absence of geographical barriers (e.g. Hellberg et al. 2002, Carr et al. 2003, Palumbi 2003). However, there is little direct evidence that marine populations are demographically open and broadly connected over large spatial scales with several studies highlighting the heterogeneity in dispersal scale among marine species (e.g. Kinlan \& Gaines 2003, Kinlan et al. 2005, Bowen et al. 2006, Cowen et al. 2007, Weersing \& Toonen 2009, Riginos et al. 2011). Our study indicates restricted gene flow between populations, suggested by the observed isolationby-distance effect. Geographical distance explained almost $40 \%$ of the genetic variation along the distribution range. This suggests that populations of $S$. plana are self-recruiting. Local retention has been observed in several marine populations (e.g. Swearer et al. 2002, Jones et al. 2005, Almany et al. 2007, Bradbury et al. 2008, Galindo et al. 2010) and it may be related to the species' ecological and habitat characteristics (Swearer et al. 2002, Cowen \& Sponaugle 2009). Moreover, although $S$. plana populations show high haplotype diversity, the observed values are relatively low when compared to other marine bivalves (Table S4 in the supplement), which may also be an effect of local retention. In this sense, isolation may be associated with $S$. plana's habitat-related, patchy spatial distribution. The low levels of genetic differentiation observed between groups may then not be a result of high gene flow but instead of large effective population sizes, in combination with the recent population expansion. The low estimated migration rates between groups constitute further evidence of contemporary isolation and ongoing divergence.

In the absence of gene flow, selection and genetic drift will be the initial driving forces of interpopulation differentiation by acting on existing genetic variation (Hellberg et al. 2002). Patterns of reduced neutral variation can be produced by both selective sweeps (Maynard Smith \& Haigh 1974, Kaplan et al. 1989) and background selection (Charlesworth et al. 1993, Hudson \& Kaplan 1995). As selective sweep is a process by which a selected mutation reduces variability in linked neutral sites as it increases in frequency in the population (Nielsen 2005). Background selection can occur when deleterious alleles are maintained by recurrent mutation (Charlesworth et al. 1993), which also reduces neutral diversity since the elimination of a deleterious mutation lowers the frequencies of any associated neutral or nearly neutral variants (Kreitman \& Akashi 1995). The frequency distribution of segregating mutations may help distinguish these 2 processes. While a selective sweep will cause an excess of private alleles leading 
to a star-like genealogy of the marker considered, this is not the case in background selection (Slatkin 1985, Charlesworth et al. 1993, Kreitman \& Akashi 1995). The star-shaped network observed for Scrobicularia plana suggests that background selection is not the cause of the low levels of differentiation. A similar population structure could, however, be observed due to demographic causes such as the recovery of variation following a population bottleneck. The reduction in population size is likely to eliminate many rare variants, reducing polymorphism. As the population recovers, a rapid expansion leads to new (rare) mutations, which results in an apparent excess in allelic diversity (Maruyama \& Fuerst 1985, Simonsen et al. 1995). Comparisons of other species from the same region can help to distinguish between potential biogeographical scenarios (Avise 2000) and mechanisms. The population structure of $S$. plana is distinct from what has been observed for either Macoma balthica (Luttikhuizen et al. 2003) or Cerastoderma edule (Krakau et al. 2012) from the same area. M. balthica consists of deeply diverged lineages that may be explained by considerably longer divergence times. Divergence time does not, however, seem to explain the differences between $S$. plana and C. edule with the later showing a more structured minimum spanning network despite similar divergence times. It is thus likely that the 2 species coped with the LGM differently through differential habitat selection. At present, population genetic surveys are still mainly conducted with markers assumed to be neutral so that the effects of selection cannot be discerned. To distinguish between demographic and selective causes of a recent reduction of genetic variability, different loci need to be analyzed since demographic events apply to the whole genome while selective events affect only distinct regions of the genome (Galtier et al. 2000). Note, however, that if selection is operating, the molecular clock hypothesis may not hold (Tajima 1993). In addition, rates of molecular evolution may vary considerably, both through time and among lineages (Smith \& Peterson 2002), which emphasizes once again the need to analyze other genetic markers and interpret molecular clock estimates with due caution.

\section{The last glacial maximum}

During the LGM, the extension of ice sheets as far south as the northern coast of the Iberian Peninsula (Frenzel et al. 1992) caused Scrobicularia plana's northern edge of distribution to likely contract to that area. As the ice retracted, new habitats became available, which would have allowed the northern spread from its periglacial refugia. This postglacial recolonization would have led to a loss of genetic diversity along the leading edge as a consequence of random genetic drift, resulting in a gradient of decreasing genetic variation with increasing latitude (Hewitt 2004).

Although individual populations of Scrobicularia plana have considerable variation in haplotype diversity, a general decreasing trend with increasing latitude (although non-significant) is observed. Four locations, however, stand out due to their higher haplotype diversity and presence of private haplotypes: Trondheim, Roscoff, Algarve and Pisa. A significant difference has been observed between the haplotype diversity values for these 4 locations and those of the remaining populations using a 1-way analysis of variance (ANOVA, $p<0.001$ ). It is probable that these locations served as refugia (e.g. Hoarau et al. 2007, Maggs et al. 2008, Olsen et al. 2010).

The Iberian Peninsula and the Mediterranean Sea are widely recognized glacial refugia as several marine species were confined to those areas as ice sheets expanded south (e.g. Consuegra et al. 2002, Gysels et al. 2004, Sá-Pinto et al. 2005, Chevolot et al. 2006, Hoarau et al. 2007, Mäkinen \& Merilä 2008). The high haplotype diversity observed for the populations of Pisa and Algarve and the high level of differentiation of the Mediterranean population do suggest that these locations served as refugia for Scrobicularia plana.

The Brittany/English Channel area is also a wellknown refuge for marine species (Coyer et al. 2003, Provan et al. 2005, Chevolot et al. 2006, Hoarau et al. 2007, Remerie et al. 2009, Campo et al. 2010, Olsen et al. 2010, Krakau et al. 2012). Scrobicularia plana also appears to have had a refuge population in this area as suggested by the high haplotype diversity of the Brittany sample, with only 2 southern populations presenting higher values. The presence of this refugial area could be explained by the drop in sea-level during the LGM (Frenzel et al. 1992), which exposed an ice-free terrestrial depression in the nascent English Channel, known as the Hurd Deep (Lericolais et al. 1995, 2003). This depression may have persisted as a marine lake in which marine organisms were able to survive until sea levels began to rise after the LGM (Provan et al. 2005).

Northern Norway, on the other hand, is not commonly recognized as a marine refuge. Although icefree areas in Scandinavia (Sutherland 1984, Vorren 
et al. 1988, Svendsen et al. 2004) suggest that this area may also have served as a northern refuge, evidence remains scant (Cerastoderma edule, Krakau et al. 2012 and the fucoid macroalga Fucus distichus, Coyer et al. 2011). The high haplotype diversity observed for the Norwegian sample, including 4 private alleles, is consistent with a northern refugium for Scrobicularia plana. Moreover, as the splitting of the Trondheim group precedes the LGM (see Table 4), the high variability of the Norwegian population is most likely not a result of a recolonization event but of the presence of a glacial refugium.

In summary, genetic diversity patterns are commonly used to determine range expansion routes. In our study, the high genetic diversity and heterogeneity of Scrobicularia plana populations in glaciated areas (Brittany Peninsula and Scandinavia) suggest a colonization of these areas prior to the LGM and survival in refugial areas. Many marine species follow this pre-LGM expansion model (e.g. Luttikhuizen et al. 2003, Gysels et al. 2004, Provan et al. 2005, Chevolot et al. 2006, Hoarau et al. 2007, Maggs et al. 2008, Campo et al. 2010), with their ability to persist in glaciated areas depending on the species' biological and ecological constraints. However, it is also important to note that other processes can alter haplotype composition such as local extinction events, genetic drift, or a selective sweep since the LGM.

\section{CONCLUSIONS}

The present study revealed a weak population genetic structure of the bivalve Scrobicularia plana but a significant isolation-by-distance effect, with the species' patchy spatial distribution likely contributing to low connectivity. S. plana has undergone recent expansion between 0.30 and $1.10 \mathrm{Mya}$, which in combination with the high population sizes, explains the weak geographic pattern of genetic variation. During the LGM, S. plana would have retreated to southern Europe, although some populations likely survived in ice-free areas along the Brittany Peninsula and Scandinavia, the latter only recently recognized as a glacial refuge for marine species (Coyer et al. 2011, Krakau et al. 2012). Results were, however, obtained using only mitochondrial COI data. Since different genetic markers can reflect different aspects of population biology and history, only by combining data from several markers is fully understanding the complex demographic history of a species possible (Eytan \& Hellberg 2010).
Acknowledgements. This study was supported by the Portuguese Foundation for Science and Technology through the grant awarded to S.S. (SFRH/BD/28370/2006). Thanks are due to all the people that provided samples for the genetic analysis: A. Whitaker, A. Amaral, B. Langston, C. Casagranda, C. Carvalho, C. Trombini, H. Witte, J. Drent, H. Drent, J. Junoy, M. Dias, M. Yates, N. Anadon, P. Bocher, U. Steeger and V. Freitas. In addition, we thank A. Bol for help with the molecular work as well as C. Heip for comments on earlier versions of the paper.

\section{LITERATURE CITED}

Almany GR, Berumen ML, Thorrold SR, Planes S, Jones GP (2007) Local replenishment of coral reef fish populations in a marine reserve. Science 316:742-744

Avise JC (2000) Phylogeography: the history and formation of species. Harvard University Press, Cambridge, MA

Baker P, Austin JD, Bowen BW, Baker SM (2008) Rangewide population structure and history of the northern quahog (Merceneria merceneria) inferred from mitochondrial DNA sequence data. ICES J Mar Sci 65: 155-163

Barber PH, Palumbi SR, Erdmann MV, Moosa MK (2000) Biogeography: a marine Wallace's line? Nature 406: 692-693

Becker BJ, Levin LA, Fodrie FJ, McMillan PA (2007) Complex larval connectivity patterns among marine invertebrate populations. Proc Natl Acad Sci USA 104: 3267-3272

Benjamini Y, Hochberg Y (1995) Controlling the false discovery rate: a practical and powerful approach to multiple testing. J R Stat Soc B 57:289-300

Bocher P, Piersma T, Dekinga A, Kraan C, Yates MG, Guyot T, Folmer EO, Radenac G (2007) Site- and speciesspecific distribution patterns of molluscs at five intertidal soft-sediment areas in northwest Europe during a single winter. Mar Biol 151:577-594

> Bowen BW, Bass AL, Muss A, Carlin J, Robertson DR (2006) Phylogeography of two Atlantic squirrelfishes (Family Holocentridae): exploring links between pelagic larval duration and population connectivity. Mar Biol 149: 899-913

> Bradbury IR, Bentzen P (2007) Non-linear genetic isolation by distance: implications for dispersal estimation in anadromous and marine fish populations. Mar Ecol Prog Ser 340:245-257

Bradbury IR, Campana SE, Bentzen P (2008) Low genetic connectivity in an estuarine fish with pelagic larvae. Can J Fish Aquat Sci 65:147-158

Bradwell T, Stoker MS, Golledge NR, Wilson CK and others (2008) The northern sector of the last British Ice Sheet: maximum extent and demise. Earth Sci Rev 88:207-226

> Campo D, Molares J, Garcia L, Fernandez-Rueda P, GarciaGonzalez C, Garcia-Vazquez E (2010) Phylogeography of the European stalked barnacle (Pollicipes pollicipes): identification of glacial refugia. Mar Biol 157:147-156

Carr MH, Neigel JE, Estes JA, Andelman S, Warner RR, Largier JL (2003) Comparing marine and terrestrial ecosystems: implications for the design of coastal marine reserves. Ecol Appl 13:90-107

> Charlesworth B, Morgan MT, Charlesworth D (1993) The effect of deleterious mutations on neutral molecular variation. Genetics 134:1289-1303 
Chevolot M, Hoarau G, Rijnsdorp AD, Stam WT, Olsen JL (2006) Phylogeography and population structure of thornback rays (Raja clavata L., Rajidae). Mol Ecol 15: 3693-3705

Coan EV, Scott PV, Bernard FR (2000) Bivalve seashells of western North America: marine bivalve mollusks from Arctic Alaska to Baja California. Santa Barbara Museum of Natural History, Santa Barbara, CA

Consuegra S, García De Leániz C, Serdio A, González Morales M, Straus LG, Knox D, Verspoor E (2002) Mitochondrial DNA variation in Pleistocene and modern Atlantic salmon from the Iberian glacial refugium. Mol Ecol 11:2037-2048

Cowen RK, Sponaugle S (2009) Larval dispersal and marine population connectivity. Annu Rev Mar Sci 1:443-466

Cowen RK, Gawarkiewicz G, Pineda J, Thorrold SR, Werner FE (2007) Population connectivity in marine systems: an overview. Oceanography 20:14-21

Cox LR, Newell ND, Boyd DW, Branson CC and others (1969) Mollusca 6, Vol 1. In: Moore RC, Teichert C (eds) Treatise on invertebrate paleontology, Part N. The Geological Society of America, Boulder, CO, p 1-489

> Coyer JA, Peters AF, Stam WT, Olsen JL (2003) Post-ice age recolonization and differentiation of Fucus serratus L.(Phaeophyceae; Fucaceae) populations in northern Europe. Mol Ecol 12:1817-1829

> Coyer JA, Hoarau G, Van Schaik J, Luijckx P, Olsen JL (2011) Trans-Pacific and trans-Arctic pathways of the intertidal macroalga Fucus distichus L. reveal multiple glacial refugia and colonizations from the North Pacific to the North Atlantic. J Biogeogr 38:756-771

Crandall ED, Taffel JR, Barber PH (2010) High gene flow due to pelagic larval dispersal among South Pacific archipelagos in two amphidromous gastropods (Neritomorpha: Neritidae). Heredity 104:563-572

Dawson AG (1992) Ice age earth: late Quaternary geology and climate. Routledge, London

> Domingues CP, Creer S, Taylor MI, Queiroga H, Carvalho GR (2010) Genetic structure of Carcinus maenas within its native range: larval dispersal and oceanographic variability. Mar Ecol Prog Ser 410:111-123

Excoffier L, Laval G, Schneider S (2005) Arlequin (version 3.0): an integrated software package for population genetics data analysis. Evol Bioinform Online 1:47-50

Eytan RI, Hellberg ME (2010) Nuclear and mitochondrial sequence data reveal and conceal different demographic histories and population genetic processes in Caribbean reef fishes. Evolution 64:3380-3397

Folmer O, Black M, Hoeh W, Lutz R, Vrijenhoek R (1994) DNA primers for amplification of mitochondrial cytochrome c oxidase subunit 1 from diverse metazoan invertebrates. Mol Mar Biol Biotechnol 3:294-299

Frenkiel L, Mouëza M (1979) Développement larvaire de deux Tellinacea, Scrobicularia plana (Semelidae) et Donax vittatus (Donacidae). Mar Biol 55:187-195

Frenzel B, Pécsi M, Velichko AA (1992) Atlas of paleoclimates and paleoenvironments of the Northern Hemisphere: Late Pleistocene-Holocene. Geographical Research Institute, Hungarian Academy of Sciences, Budapest

> Fu YX (1997) Statistical tests of neutrality of mutations against population growth, hitchhiking and background selection. Genetics 147:915-925

Galarza JA, Carreras-Carbonell J, Macpherson E, Pascual M, Roques S, Turner GF, Rico C (2009) The influence of oceanographic fronts and early-life-history traits on connectivity among littoral fish species. Proc Natl Acad Sci USA 106:1473

> Galindo HM, Pfeiffer-Herbert AS, McManus MA, Chao Y, Chai F, Palumbi SR (2010) Seascape genetics along a steep cline: using genetic patterns to test predictions of marine larval dispersal. Mol Ecol 19:3692-3707

- Galtier N, Depaulis F, Barton NH (2000) Detecting bottlenecks and selective sweeps from DNA sequence polymorphism. Genetics 155:981-987

Guindon S, Gascuel O (2003) A simple, fast, and accurate algorithm to estimate large phylogenies by maximum likelihood. Syst Biol 52:696-704

Gysels ES, Hellemans B, Pampoulie C, Volckaert FAM (2004) Phylogeography of the common goby, Pomatoschistus microps, with particular emphasis on the colonization of the Mediterranean and the North Sea. Mol Ecol 13:403-417

Hall TA BioEdit: a user-friendly biological sequence alignment editor and analysis program for Windows 95/98/ NT. Proc Nucleic Acids Symp Ser 41:95-98

> Harpending HC (1994) Signature of ancient population growth in a low-resolution mitochondrial DNA mismatch distribution. Hum Biol 66:591-600

Hellberg ME, Burton RS, Neigel JE, Palumbi SR (2002) Genetic assessment of connectivity among marine populations. Bull Mar Sci 70:273-290

- Hewitt GM (2000) The genetic legacy of the Quaternary ice ages. Nature 405:907-913

Hewitt GM (2004) Genetic consequences of climatic oscillations in the Quaternary. Philos Trans R Soc Lond B 359: $183-196$

- Hey J (2010) Isolation with migration models for more than two populations. Mol Biol Evol 27:905-920

> Hoarau G, Rijnsdorp AD, Van der Veer HW, Stam WT, Olsen JL (2002) Population structure of plaice (Pleuronectes platessa L.) in northern Europe: microsatellites revealed large-scale spatial and temporal homogeneity. Mol Ecol 11:1165-1176

> Hoarau G, Coyer JA, Veldsink JH, Stam WT, Olsen JL (2007) Glacial refugia and recolonization pathways in the brown seaweed Fucus serratus. Mol Ecol 16:3606-3616

> Hoffman JI, Clarke A, Linse K, Peck LS (2011) Effects of brooding and broadcasting reproductive modes on the population genetic structure of two Antarctic gastropod molluscs. Mar Biol 158:287-296

Holmes SP, Dekker R, Williams ID (2004) Population dynamics and genetic differentiation in the bivalve mollusc Abra tenuis: aplanic dispersal. Mar Ecol Prog Ser 268: 131-140

Hudson RR, Kaplan NL (1995) The coalescent process and background selection. Philos Trans R Soc Lond B 349: $19-23$

Ilves KL, Huang W, Wares JP, Hickerson MJ (2010) Colonization and/or mitochondrial selective sweeps across the North Atlantic intertidal assemblage revealed by multi-taxa approximate Bayesian computation. Mol Ecol 19:4505-4519

Jensen JL, Bohonak AJ, Kelley ST (2005) Isolation by distance, web service. BMC Genet 6:13

> Johnson MP, Allcock AL, Pye SE, Chambers SJ, Fitton DM (2001) The effects of dispersal mode on the spatial distribution patterns of intertidal molluscs. J Anim Ecol 70: 641-649

Jones GP, Planes S, Thorrold SR (2005) Coral reef fish larvae 
settle close to home. Curr Biol 15:1314-1318

Kaplan NL, Hudson RR, Langley CH (1989) The 'hitchhiking effect' revisited. Genetics 123:887-899

Keegan BF (1986) The COST 647 project on coastal benthic ecology: a perspective. Hydrobiologia 142:IX-XII

Kimura M (1980) A simple method for estimating evolutionary rates of base substitutions through comparative studies of nucleotide sequences. J Mol Evol 16:111-120

Kinlan BP, Gaines SD (2003) Propagule dispersal in marine and terrestrial environments: a community perspective. Ecology 84:2007-2020

Kinlan BP, Gaines SD, Lester SE (2005) Propagule dispersal and the scales of marine community process. Divers Distrib 11:139-148

Krakau M, Jacobsen S, Jensen KT, Reise K (2012) The cockle Cerastoderma edule at Northeast Atlantic shores: genetic signatures of glacial refugia. Mar Biol 159: 221-230

Kreitman M, Akashi H (1995) Molecular evidence for natural selection. Annu Rev Ecol Syst 26:403-422

Kukla GJ, Bender ML, de Beaulieu JL, Bond G and others (2002) Last interglacial climates. Quat Res 58:2-13

Lericolais G, Auffret JP, Bourillet JF, Berne S, Guennoc P, Le Drezen E, Normand A, Guillocheau F (1995) The enigmatic English Channel Hurd Deep: morphological study and sedimentary infill revealed by high resolution geophysical techniques. C R Acad Sci, Ser 2, Sci Terre Planetes 321:39-46 (in French)

Lericolais G, Auffret JP, Bourillet JF (2003) The Quaternary Channel River: seismic stratigraphy of its palaeo-valleys and deeps. J Quat Sci 18:245-260

Lester SE, Ruttenberg BI, Gaines SD, Kinlan BP (2007) The relationship between dispersal ability and geographic range size. Ecol Lett 10:745-758

Librado P, Rozas J (2009) DnaSP v5: a software for comprehensive analysis of DNA polymorphism data. Bioinformatics 25:1451-1452

Luttikhuizen PC, Drent J, Baker AJ (2003) Disjunct distribution of highly diverged mitochondrial lineage clade and population subdivision in a marine bivalve with pelagic larval dispersal. Mol Ecol 12:2215-2229

Maggs CA, Castilho R, Foltz D, Henzler C and others (2008) Evaluating signatures of glacial refugia for North Atlantic benthic marine taxa. Ecology 89:S108-S122

> Mäkinen HS, Merilä J (2008) Mitochondrial DNA phylogeography of the three-spined stickleback (Gasterosteus aculeatus) in Europe-evidence for multiple glacial refugia. Mol Phylogenet Evol 46:167-182

Maruyama T, Fuerst PA (1985) Population bottlenecks and nonequilibrium models in population genetics. III. Genic homozygosity in populations which experience periodic bottlenecks. Genetics 111:691-703

> Maynard Smith J, Haigh J (1974) The hitch-hiking effect of a favourable gene. Genet Res 23:23-35

Nei M (1987) Molecular evolutionary genetics. Columbia University Press, New York, NY

Nielsen R (2005) Molecular signatures of natural selection. Annu Rev Genet 39:197-218

> Olsen JL, Zechman FW, Hoarau G, Coyer JA, Stam WT, Valero M, Åberg P (2010) The phylogeographic architecture of the fucoid seaweed Ascophyllum nodosum: an intertidal 'marine tree' and survivor of more than one glacial-interglacial cycle. J Biogeogr 37:842-856

- Palero F, Abelló P, Macpherson E, Gristina M, Pascual M (2008) Phylogeography of the European spiny lobster
(Palinurus elephas): influence of current oceanographical features and historical processes. Mol Phylogenet Evol 48:708-717

Palumbi SR (2003) Population genetics, demographic connectivity, and the design of marine reserves. Ecol Appl 13:146-158

Pohlo R (1982) Evolution of the Tellinacea (Bivalvia). J Molluscan Stud 48:245-256

Posada D (2008) jModelTest: phylogenetic model averaging. Mol Biol Evol 25:1253-1256

Provan J, Wattier RA, Maggs CA (2005) Phylogeographic analysis of the red seaweed Palmaria palmata reveals a Pleistocene marine glacial refugium in the English Channel. Mol Ecol 14:793-803

Ramos-Onsins SE, Rozas J (2002) Statistical properties of new neutrality tests against population growth. Mol Biol Evol 19:2092-2100

> Rawson PD, Harper FM (2009) Colonization of the northwest Atlantic by the blue mussel, Mytilus trossulus postdates the last glacial maximum. Mar Biol 156:1857-1868

Reece JS, Bowen BW, Smith DG, Larson A (2011) Comparative phylogeography of four Indo-Pacific moray eel species (Muraenidae) reveals comparable ocean-wide genetic connectivity despite five-fold differences in available adult habitat. Mar Ecol Prog Ser 437:269-277

> Remerie T, Vierstraete A, Weekers PHH, Vanfleteren JR, Vanreusel A (2009) Phylogeography of an estuarine mysid, Neomysis integer (Crustacea, Mysida), along the north east Atlantic coasts. J Biogeogr 36:39-54

Riginos C, Henzler CM (2008) Patterns of mtDNA diversity in North Atlantic populations of the mussel Mytilus edulis. Mar Biol 155:399-412

> Riginos C, Victor BC (2001) Larval spatial distributions and other early life-history characteristics predict genetic differentiation in eastern Pacific blennioid fishes. Proc R Soc Lond B 268:1931-1936

> Riginos C, Douglas KE, Jin Y, Shanahan DF, Treml EA (2011) Effects of geography and life history traits on genetic differentiation in benthic marine fishes. Ecography 34:566-575

> Rogers AR, Harpending HC (1992) Population growth makes waves in the distribution of pairwise genetic differences. Mol Biol Evol 9:552-569

Rousset F (1997) Genetic differentiation and estimation of gene flow from $F$-statistics under isolation by distance. Genetics 145:1219-1228

Rozen S, Skaletsky H (2000) Primer3 on the WWW for general users and for biologist programmers. Methods Mol Biol 132:365-386

> Sá-Pinto A, Branco M, Harris DJ, Alexandrino P (2005) Phylogeny and phylogeography of the genus Patella based on mitochondrial DNA sequence data. J Exp Mar Biol Ecol 325:95-110

Selkoe KA, Toonen RJ (2011) Marine connectivity: a new look at pelagic larval duration and genetic metrics of dispersal. Mar Ecol Prog Ser 436:291-305

Shanks AL, Grantham BA, Carr MH (2003) Propagule dispersal distance and the size and spacing of marine reserves. Ecol Appl 13:159-169

Simonsen KL, Churchill GA, Aquadro CF (1995) Properties of statistical tests of neutrality for DNA polymorphism data. Genetics 141:413-429

Skibinski DOF, McNee AR, Beardmore JA (1978) Protein variation in the marine bivalve Scrobicularia plana. Anim Genet 9:223-228 
Slatkin M (1985) Rare alleles as indicators of gene flow. Evolution 39:53-65

Slatkin M, Hudson RR (1991) Pairwise comparisons of mitochondrial DNA sequences in stable and exponentially growing populations. Genetics 129:555-562

Small ST, Wares JP (2010) Phylogeography and marine retention. J Biogeogr 37:781-784

Smith AB, Peterson KJ (2002) Dating the time of origin of major clades: molecular clocks and the fossil record. Annu Rev Earth Planet Sci 30:65-88

Strasser CA, Barber PH (2009) Limited genetic variation and structure in softshell clams (Mya arenaria) across their native and introduced range. Conserv Genet 10:803-814

Sutherland DG (1984) The Quaternary deposits and landforms of Scotland and the neighbouring shelves: a review. Quat Sci Rev 3:157-254

Svendsen JI, Alexanderson H, Astakhov VI, Demidov I and others (2004) Late Quaternary ice sheet history of northern Eurasia. Quat Sci Rev 23:1229-1271

Swearer SE, Shima JS, Hellberg ME, Thorrold SR and others (2002) Evidence of self-recruitment in demersal marine populations. Bull Mar Sci 70:251-271

Tajima F (1983) Evolutionary relationship of DNA sequences in finite populations. Genetics 105:437-460

Tajima F (1989) Statistical method for testing the neutral mutation hypothesis by DNA polymorphism. Genetics 123:585-595

Tajima F (1993) Simple methods for testing the molecular

Editorial responsibility: Hans-Heinrich Janssen, Oldendorf/Luhe, Germany evolutionary clock hypothesis. Genetics 135:599-607

Tarnowska K, Chenuil A, Nikula R, Féral JP, Wolowicz M (2010) Complex genetic population structure of the bivalve Cerastoderma glaucum in a highly fragmented lagoon habitat. Mar Ecol Prog Ser 406:173-184

Tebble N (1976) British bivalve seashells: a handbook for identification, 2nd edn. HM Stationery Office, Edinburgh

Thrush SF, Hewitt JE, Gibbs M, Lundquist C, Norkko A (2006) Functional role of large organisms in intertidal communities: community effects and ecosystem function. Ecosystems 9:1029-1040

> Väinölä R (2003) Repeated trans-Arctic invasions in littoral bivalves: molecular zoogeography of the Macoma balthica complex. Mar Biol 143:935-946

> Villesen P (2007) FaBox: an online toolbox for FASTA sequences. Mol Ecol Notes 7:965-968

> Vorren TO, Vorren KD, Alm T, Gulliksen S, Løvlie R (1988) The last deglaciation (20,000 to 11,000 B.P.) on Andoya, northern Norway. Boreas 17:41-77

> Wares JP, Cunningham CW (2001) Phylogeography and historical ecology of the North Atlantic intertidal. Evolution 55:2455-2469

> Weersing K, Toonen RJ (2009) Population genetics, larval dispersal, and connectivity in marine systems. Mar Ecol Prog Ser 393:1-12

White C, Selkoe KA, Watson J, Siegel DA, Zacherl DC, Toonen RJ (2010) Ocean currents help explain population genetic structure. Proc R Soc Lond B 277:1685-1694

Submitted: November 8, 2011; Accepted: May 21, 2012

Proofs received from author(s): August 6, 2012 